\title{
PUTATIVE BIOFILM-FORMING ORGANISMS IN THE HUMAN VASCULATURE: EXPANDED CASE REPORTS AND REVIEW OF THE LITERATURE
}

\author{
Stephen Eugene Fry', Jeremy Eugene Ellis', Matthew Andrew Shabilla', \\ Delyn Lorene Martinez', Renatta Schwarz ${ }^{2}$, Richard Heuser ${ }^{3}$, Constantine Moschonas ${ }^{4}$ \\ 'Fry Laboratories, LLC, Scottsdale, USA \\ 2St. Luke's Heart Center, Phoenix, Arizona, USA \\ 3St. Luke's Phoenix Heart Center, USA \\ ${ }^{4}$ Four Peaks Neurology, Scottsdale, USA
}

\author{
ORIGINAL PAPER \\ Phlebological Review 2014; 22, 1: 24-37 \\ DOl: 10.5114/pr.2014.46050 \\ Submitted: 13.06 .2014 \\ Accepted: 14.07.2014
}

\section{ADDRESS FOR CORRESPONDENCE}

Dr Stephen Eugene Fry

Fry Laboratories, LLC,

15720 N. Greenway Hayden Loop,

Suite 3, 85260 Scottsdale, USA

e-mail: stfry@aol.com

\begin{abstract}
Objectives: New technologies, particularly in the field of clinical metagenomics, have initiation is poorly understood. Here we present a series of six patients suffering from diseases with potential microbial involvement: systemic lupus erythematosus, chronic Material and methods: Peripheral blood (first five cases) and suction debris from carotid percutaneous angioplasty (arteriosclerosis) were refrigerated and transported to the site of analysis. DNA was extracted using the standard QIAamp DNA Blood Mini and Protozoal Extraction kits. Bacterial-specific DNA sequences were amplified and subsequently barcoded for DNA sequencing with 16S rRNA-directed primers flanking the variable regions 1 and 2 and variable regions 4 and 5, respectively. Protozoal-specific DNA sequences were amplified and subsequently barcoded for DNA sequencing using low stringency conditions and primers directed to variable regions in the $18 \mathrm{~S}$ rRNA gene.

Results: We found previously unreported mixed bacterial and protozoal biofilm communities in all samples. In all six disease types we revealed protozoa, being close relatives to known aquatic-based protozoa, such as: Oblongichytrium, Chrysocapsa vernalis, Ochromonas, and Perkinsus qugwadi. In a blood sample from the patient with lupus erythematosus DNA stains and culture studies revealed an unknown protozoan exhibiting profound biofilm-forming capability: candidatus Protomyxzoa rheumatica. Conclusions: Discovery of these potentially pathogenic protozoa in human blood may be of great clinical relevance. However, our preliminary results should be confirmed by independent researchers, and the role of biofilm-forming protozoa in human disease should be elucidated.
\end{abstract}

Key words: protozoa, clinical metagenomics, multiple sclerosis, biofilm, plaque.

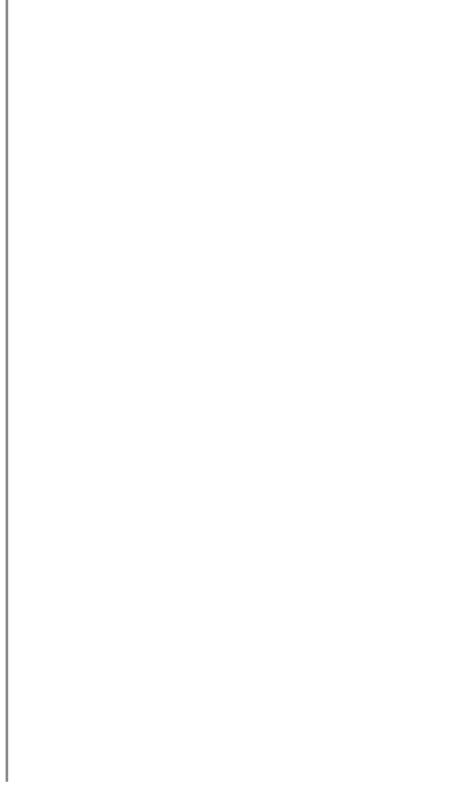

\section{INTRODUCTION}

There are a variety of extensively studied chronic illnesses whereby an initiating aetiological event has yet to be conclusively identified, representing a gap in our current medical framework. The presence of a variety of bacterial and/or viral agents has been frequently observed in association with this class of diseases; however, a single conclusive aetiological agent has yet to be identified. Systemic lupus erythematosus (SLE), chronic fatigue syndrome (CFS), fibromyalgia (FM), multiple sclerosis (MS), amyotrophic lateral sclerosis (ALS), and arteriosclerosis all display a variety of chronic symptoms and inflammatory features. These diseases suffer from significant treatment limitations that range from palliative measures, immunosuppressive agents, lipid management, and vascular interventions.

Many previously intractable chronic disorders have been shown to be closely associated with polymicrobial biofilm communities $[1,2]$. These microbial communities are characterised by adherent, polysaccharide-secreting communal microorganisms. The communal nature of these organisms and the surrounding biofilm matrix results in significant hurdles for treatment as they promote immune system evasion, antimicrobial treatment resistance, and inherent recalcitrance [3]. In the human arterial 
system, biofilm bacteria have been documented as contributors to arterial plaque $[4,5]$. There are only a handful of protozoal microorganisms reported to have biofilm-forming properties. Among these are Acanthamoeba sp., Trypanosoma brucei, Pneumocystis carinii, and our initial report of protozoan biofilm communities in ALS patients [6-8].

A significant limitation in the study and the involvement of polymicrobial infections and biofilm diseases is the traditional reliance on Koch's postulates. Koch's postulates assume that a single organism will occur in every case of the disease, such an organism occurs in no other disease or in the absence of disease, and once grown in pure culture it can induce disease [9]. Research has demonstrated that a single causal organism may not be easily identified due to its dependence on supportive factors provided from a polymicrobial community. Furthermore, virulence factors may contribute to altering the pathogenic potential of an organism, so the organisms may be more widespread than is acceptable according to Koch's postulates. Lastly, over the last decade molecular technologies have highlighted significant technological deficiencies in our microbial knowledge, with less than an estimated $2 \%$ of all bacteria being currently cultivatable [10]. This deficiency is further highlighted in critical medical microbiology, such as sepsis in the intensive care unit, whereby bacteria are unreliably cultivable 10-60\% of the time $[11,12]$. Taken in total, these limitations have resulted in reconsideration of Koch's postulates [13].

Next Generation Sequencing (NGS) and metagenomic analysis may be used to elucidate and define important trends of microbial populations and disease [14-16]. We hypothesise that by using modern clinical metagenomics and broad-spectrum analysis, previously unreported microbial phenomena may be detected and characterised in these diseases. In this article we document six examples of biofilm communities: five isolated from peripheral venous system samples from SLE, FM, CFS, MS, and ALS, and a single sample from carotid angioplasty. A review of the literature is presented to provide feasibility and context for these findings. If future studies continue to demonstrate similar correlative findings, this may represent a new class of microbial illness.

\section{MATERIAL AND METHODS \\ Patient selection and consent}

All patients provided written, informed consent. All patients met inclusion criteria for the classification of the disease of interest. Systemic lupus erythematosus, ALS, and FM cases were obtained through patient consent as part of single case studies. The arterial case is part of an ongoing study that is approved by St. Luke's Hospital IRB (Protocol\# 09.072012, Study\# 1136445). MS and CFS cases are part of ongoing studies approved by the Western Independent Review Board (WIRB);
(Protocol\# 21211127, Study\# 1133561). This study was conducted in accordance with the Declaration of Helsinki 1975-2008.

\section{Sample collection and processing}

Peripheral blood (BD Vacutainer K2 EDTA, about $3 \mathrm{ml}$ ) and suction debris from elective carotid percutaneous transluminal angioplasty and stenting were collected, refrigerated, and transported via rapid courier to the site of analysis. Bacterial DNA was extracted from $200 \mu \mathrm{l}$ of sample processed using the standard QIAamp DNA Blood Mini extraction kit (Qiagen) to extract total DNA with a final elution volume of $30 \mu \mathrm{l}$. Alternatively, total DNA, including Protozoal DNA, was extracted using the Protozoal Extraction kit and protocol (Fry Laboratories, L.L.C.) with a final elution volume of $30 \mu \mathrm{l}$.

\section{Stains and microscopy}

Standard fluorescence microscopy (Nikon Eclipse E600) was used to visualise and capture by photomicrograph Höechst DNA-stained [17, 18] samples (Fry Laboratories, LLC) using the appropriate filters, NIS Elements D v3.22.14 software, and DS-U2/L2 USB imager (Nikon). Digital image processing and editing was carried out using Photoshop CS 8.0 (Adobe).

\section{DNA sequence analysis}

Cloned fragment sequencing was performed by Sanger sequencing at the DNA Lab (Arizona State University, Tempe Az, USA) and was deposited in GenBank. Next Generation Sequencing and analysis was performed in-house utilising the RIDI ${ }^{\mathrm{m} x}$ system (Fry Laboratories, LLC), which was developed to complement the IonTorrent $^{\mathrm{Tm}}$ PGM sequencer. Bacterial-specific DNA sequences were amplified and subsequently barcoded for DNA sequencing with $16 \mathrm{~S}$ rRNA-directed primers flanking the variable regions 1 and 2, and variable regions 4 and 5 , respectively. Protozoal-specific DNA sequences were amplified and subsequently barcoded for DNA sequencing using low stringency conditions and primers directed to variable regions in the $18 \mathrm{~S}$ rRNA gene. All processed metagenomic data were deposited at the Sequence Read Archive (SRA) at the National Centre for Biotechnology Information.

\section{CASE REPORTS}

\section{Systemic lupus erythematosus}

After informed consent a peripheral venous blood sample was obtained from a 55-year-old Caucasian male who developed chronic fatigue in the late 1980s, which progressed to a diagnosis of SLE, meeting four of fourteen 

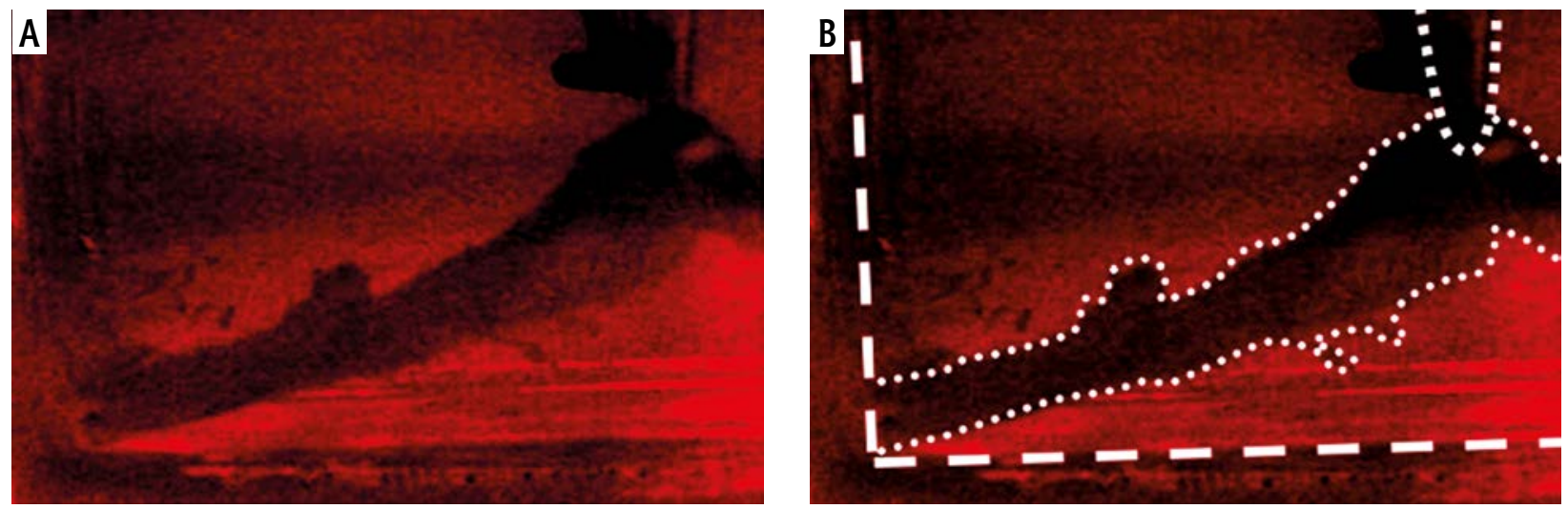

Fig. 1. Biofilm-like structures from primary culture. A) Biofilm-like material formed in primary culture from blood from an SLE patient, raised by a micropipette. B) Annotated view showing culture flask perimeter via long rectangle hash marks. Biofilm-like material indicated by circular hash marks. Pipette tip is indicated by square hash marks. Scale bar in panel A represents $1 \mathrm{~cm}$

American College of Rheumatology criteria: elevated ANA, anti-dsDNA, pulmonary interstitial fibrosis, and non-erosive arthritis [19]. Höechst DNA staining of peripheral blood exhibited evidence of a biofilm-like structure with putative indwelling organisms (Fig. 1A). Thirty millilitres of enriched eukaryotic cell culture media was spiked with $200 \mu \mathrm{l}$ of peripheral blood containing these putative biofilm communities and incubated at $37^{\circ} \mathrm{C}$. A visible biofilm-like layer evolved over seven days (Fig. 2). Due to the suspected protozoal elements in the patient sample, broad-spectrum DNA amplification from total genomic DNA harvested from blood, subsequent cloning, sequencing using semi-pan-protozoal primers, and read assembly revealed protozoal DNA fragments, which were deposited in GenBank (KJ914572). This includes a characteristic sequence of a proposed organism of particular interest tentatively named candidatus Protomyxzoa rheumatica.

\section{Chronic fatigue syndrome}

After informed consent, a peripheral venous blood sample was obtained from a 49-year-old Caucasian male who met the Centres for Disease Control and Prevention and Fukuda 1994 criteria [20, 21]. Upon microscopy with Höechst staining, biofilm-like structures were observed (Fig. 1B). Subsequent metagenomic analysis revealed significant fungoid-like protist sequences consistent with divergent Oblongichytrium sp., Schizochytrium minutum, and Schizochytrium aggregartum (SRR1301144). No sequences were identified exceeding 95\% identity, indicating these sequences may potentially represent a novel species (Table 1). Of note, the highest sequence contributor (80.6\%), Oblongichytrium sp., is related to other thraustochytrids, some of which are shellfish pathogens [22, 23].

\section{Fibromyalgia}

After informed consent, peripheral venous blood was obtained from a 55-year-old Caucasian female meeting the American College of Rheumatology criteria for fibromyalgia. A large thrombotic-like strand was recovered from a peripheral blood Vacutainer tube draw that measured approximately $28 \mathrm{~mm}$ in length and $5 \mathrm{~mm}$ in diameter when flattened on a standard microscope slide with cover glass placed on top (Fig. 1C). The large size of the putative biofilm-like strand allowed for direct manipulation via sterile glass needles and revealed a firm, gelatinous consistency. Putative bacteria were visualised in addition to larger eukaryotic-like cellular structures. The strand was collected, total DNA was harvested, and metagenomic analysis revealed a mixed population of bacteria and a potentially novel protozoal contributor. Bacteria consisting of $5 \%$ or more of the total sequences included a divergent Polaromonas napthalenivorans-like species, Rubrivivax gelatinosus, Pelomonas saccharophilia, and a divergent Smithella propionica-like organism (Table 2) (SRR1301142). Protozoal sequence analysis yielded a divergent Chrysocapsa vernalis-like organism (64\% of the total sequences) (Table 1) (SRR1301143).

\section{Multiple sclerosis}

After informed consent, peripheral venous blood was obtained from a 57-year-old female Caucasian with a history of MS meeting the McDonald Criteria and with an EDSS severity scale of 7 [24]. Höechst DNA staining of the peripheral blood showed additional biofilm-like communities (Fig. 1D). Next Generation Sequencing and clinical metagenomic analysis revealed a low sequence count of potentially incidental bacterial findings of a high percentage identity to Propionibacterium acnes and Ralstonia solanacearum: $53.8 \%$ and $46.2 \%$, respectively (Table 2) (SRR1301145). Protozoal sequence analysis yielded slightly higher sequence counts for Ochromonas danica, with $84 \%$ having $95 \%$ or greater sequence identity and the remaining $9.9 \%$ being more divergent (Table 1 ) (SRR1301146). 

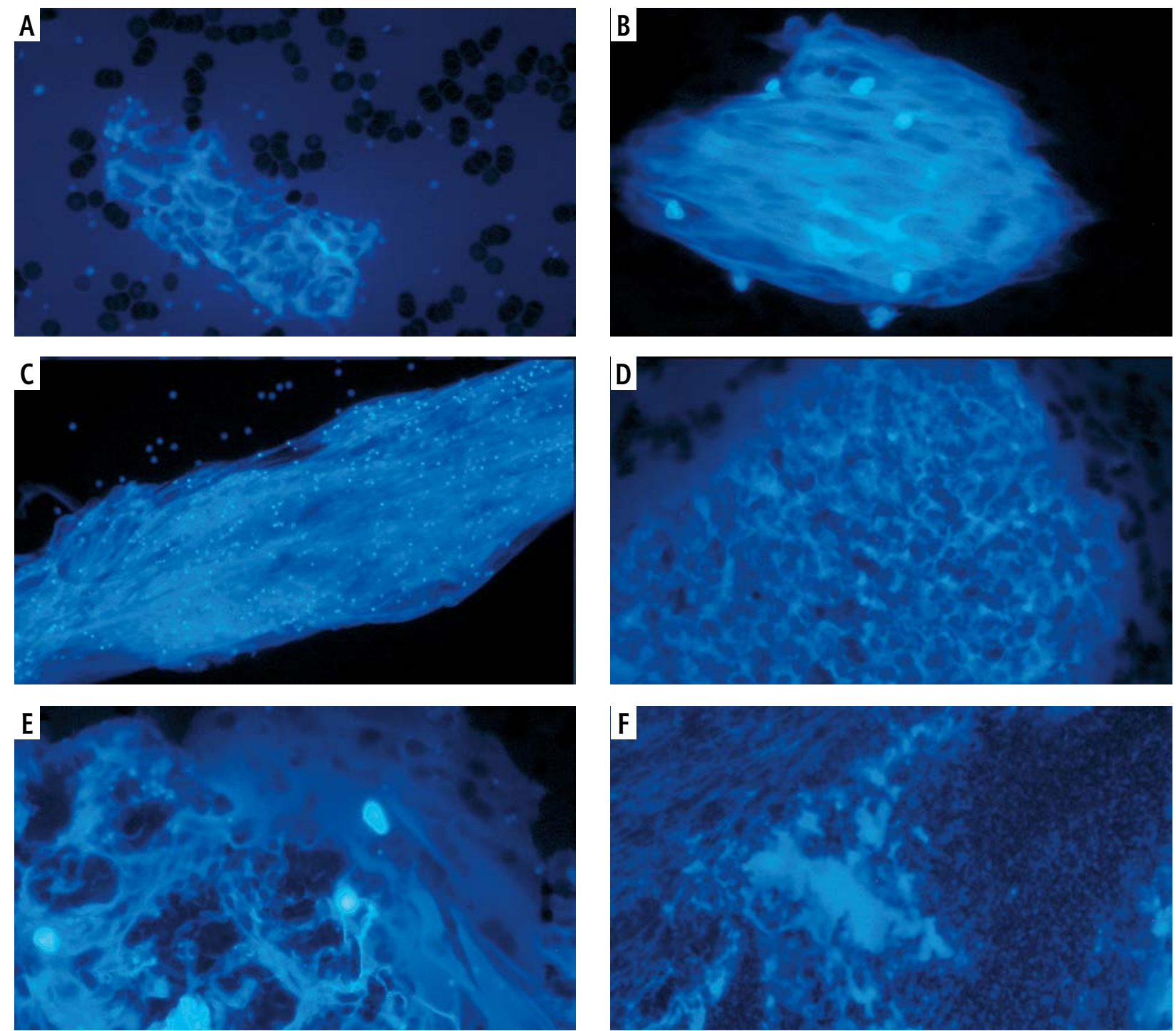

Fig. 2. Biofilm-like structures by fluorescent microscopy. A) Tight DNA positive cluster found in the blood from an SLE patient. B) Filamentous DNA positive clustering with adherent neutrophils found in the blood from a CFS patient. C) Large filamentous strand found containing many DNA-positive cells. D) Large cluster of densely packed cells with interspersed DNA-positive material found in blood from an MS patient. E) Sheet and filamentous DNA-positive material with imbedded and adherent neutrophils found in the blood of an ALS patient. F) Dense DNA-positive material found among the captured debris from a carotid angioplasty. Scale bars in $A, B, D$, and $E$ correspond to approximately $10 \mu \mathrm{m}$, while bars in $C$ and $F$ correspond to $50 \mu \mathrm{m}$

\section{Amyotrophic lateral sclerosis}

After informed consent, peripheral venous blood was obtained from a 49-year-old Caucasian male with a suspected diagnosis of ALS meeting the Awaji criteria from an independent neurologist [25]. This patient had complicating degenerative cervical disease that was not alleviated after surgical correction. Suspect microbial elements were observed by Höechst DNA staining (Fig. 1E). Clinical metagenomics using NGS revealed a detectable population of protozoa (SSR1301141) (Table 1). Of note, the primary organism detected by DNA BLAST analysis (69.4\%) was most closely related to Perkinsus qugwadi, a known aggressive oyster pathogen [26]. In retrospect, this patient acknowledged lifelong consumption of raw shellfish.

\section{Atherosclerosis angioplasty debris}

A sterile collection cup was received containing debris obtained from an elective percutaneous transluminal angioplasty of the internal carotid artery (ICA) performed at St. Luke's Catheterisation Unit, Phoenix, Arizona, USA. This sample was obtained from a 72-year-old Caucasian male with obstruction of the left ICA. Analysis of the angioplasty debris derived from the procedure by 
Table 1. Protozoal sequence findings per sample

\begin{tabular}{|c|c|c|c|c|c|}
\hline Sample & Type & Total sequences & Identified species & Sequence counts & $\%$ Contribution \\
\hline \multirow[t]{3}{*}{ CFS } & B & 29857 & Oblongichytrium species* & 15738 & 80.6 \\
\hline & & & Schizochytrium minutum* & 2961 & 15.2 \\
\hline & & & Schizochytrium aggregatum* & 465 & 2.4 \\
\hline FM & $\mathrm{F}$ & 2671 & Chrysocapsa vernalis* & 9 & 64.3 \\
\hline \multirow[t]{2}{*}{ MS } & B & 7705 & Ochromonas danica & 136 & 84.0 \\
\hline & & & Ochromonas danica* & 16 & 9.9 \\
\hline \multirow[t]{10}{*}{ ALS } & B & 130353 & Perkinsus qugwadi* & 38706 & 69.4 \\
\hline & & & Aristerostoma marinum* & 2602 & 4.7 \\
\hline & & & Perkinsus species* & 2576 & 4.6 \\
\hline & & & Colponema edaphicum* & 1761 & 3.2 \\
\hline & & & Allantion species & 1698 & 3.0 \\
\hline & & & Aureococcus anophagefferens* & 1487 & 2.7 \\
\hline & & & Dinophyceae species* & 1353 & 2.4 \\
\hline & & & Spumella species & 855 & 1.5 \\
\hline & & & Perkinsus mediterraneus* & 736 & 1.3 \\
\hline & & & Vorticella convallaria & 627 & 1.1 \\
\hline \multirow[t]{5}{*}{ AP } & A & 4825 & Perkinsus qugwadi* & 510 & 68.3 \\
\hline & & & Ochromonas species & 87 & 11.6 \\
\hline & & & Ochromonas species* & 75 & 10.0 \\
\hline & & & Allantion species & 38 & 5.1 \\
\hline & & & Chromophyton vischeri* & 11 & 1.5 \\
\hline
\end{tabular}

A - angioplasty debris; B - blood sample; F- filament; NSS - no significant sequences; *BLAST hit has < 97\% identity and < 10-75 eValue or matches another 100\% identity call, but has $<95 \%$ identity and $<100 \mathrm{bp} ;{ }^{*}$ does not total $100 \%$ as low probability sequence calls $(<5$ or $<1 \%$ ) are not reported

fluorescence microscopy revealed a complex amorphous group of prokaryotic-like and eukaryotic-like organisms (Fig. 1F). A mixed population of potentially opportunistic bacteria (SSR1300599) and two different types of protozoa were identified (SSR1300602) through NGS and subsequent metagenomic analysis. The primary identified bacteria were Blastobacter denitrificans (22.6\%), Rubrivivax gelatinosus (17.8\%), and Streptococcus mitis (7.9\%) (Table 2). The primary protozoal contributors were identified as another divergent Perkinsus qugwadi-like species (68.3\%) and an Orchomonas sp. (11.6\%) (Table 1).

\section{LITERATURE REVIEW}

\section{Systemic lupus erythematosus}

It appears that for the provocation and progression of the SLE, Epstein-Barr virus (EBV) may play a role, although it is not the primary factor responsible [27, 28]. A current model of this disease is that molecular mimic- ry by EBV could be responsible for the cross-reactivity, ultimately giving rise to the production of autoantibodies [29]. The epitopic mimicry hypothesis has also been examined for links with Burkholderia sp. because dsDNA reactive antibodies exhibit a high affinity for antigens from this class of organisms [30]. In the mouse model of SLE an infection by Toxoplasma sp. is protective against disease progression, probably through immunomodulatory effects [31]. A series of genetic risk factors have been identified as being associated with SLE. Nonetheless, they do not seem to be responsible for the development of the disease but rather for exhibiting immunomodulatory functions [32]. Mutations in the FcgRIIb receptor are known SLE risk factors that appear to result in a hyperactive immune response, increased risk of SLE, and increased resistance to infection [33-36]. In the malaria FcgRIIb-deficient mouse model, an enhanced resistance and clearance of malarial parasites has been noted [37]. It is possible that continual induction of the immune response via a chronic infection in the context of immune 
Table 2. Bacterial sequence findings per sample

\begin{tabular}{|c|c|c|c|c|c|}
\hline Sample & Type & Total Sequences & Identified Species & Sequence Counts & $\%$ Contribution $^{*}$ \\
\hline CFS & B & 13383 & NSS & NA & NA \\
\hline \multirow[t]{10}{*}{ FM } & $\mathrm{F}$ & 86834 & Polaromonas napthalenivorans* & 92 & 27.6 \\
\hline & & & Rubrivivax gelatinosus & 43 & 12.9 \\
\hline & & & Pelomonas saccharophila & 38 & 11.4 \\
\hline & & & Smithella propionica* & 17 & 5.1 \\
\hline & & & Bdellovibrio bacteriovorus* & 14 & 4.2 \\
\hline & & & Sinomonas atrocyanea* & 11 & 3.3 \\
\hline & & & Mucilaginibacter daejeonensis* & 10 & 3.0 \\
\hline & & & Acintetobacter baumanii* & 8 & 2.4 \\
\hline & & & Polynucleobacter necessarius* & 6 & 1.8 \\
\hline & & & Mucilaginibacter daejeonensis & 5 & 1.5 \\
\hline \multirow[t]{2}{*}{ MS } & B & 27998 & Propionibacterium acnes & 7 & 53.8 \\
\hline & & & Ralstonia solanacearum & 6 & 46.2 \\
\hline ALS & B & 41555 & NSS & NA & NA \\
\hline \multirow[t]{16}{*}{ AP } & A & 55973 & Blastobacter denitrificans & 339 & 22.6 \\
\hline & & & Rubrivivax gelatinosus & 267 & 17.8 \\
\hline & & & Streptococcus mitis & 119 & 7.9 \\
\hline & & & Xylophilus ampelinus & 96 & 6.4 \\
\hline & & & Streptococcus pseudopneumoniae & 77 & 5.1 \\
\hline & & & Streptococcus marimammalium & 76 & 5.1 \\
\hline & & & Curvibacter delicatus & 71 & 4.7 \\
\hline & & & Leptothrix mobilis & 69 & 4.6 \\
\hline & & & Rhodopseudomonas palustris & 43 & 2.9 \\
\hline & & & Roseateles depolymerans & 26 & 1.7 \\
\hline & & & Blastomonas natatoria* & 25 & 1.7 \\
\hline & & & Methylotenera mobilis & 25 & 1.7 \\
\hline & & & Paucibacter toxinivorans & 23 & 1.5 \\
\hline & & & Streptococcus pneumoniae & 22 & 1.5 \\
\hline & & & Rhizobium lupini & 19 & 1.3 \\
\hline & & & Diaphorobacter nitroreducens & 15 & 1.0 \\
\hline
\end{tabular}

A-angioplasty debris; B - blood sample; F- filament; NSS - no significant sequences; * ${ }^{*}$ LAST hit has < 97\% identity and < 10-75 eValue or matches another 100\% identity call, but has $<95 \%$ identity and $<100 \mathrm{bp} ;{ }^{*}$ does not total $100 \%$ as low probability sequence calls ( $<5$ or $<1 \%$ ) are not reported

hyperactivity may contribute to the total SLE risk. It is interesting to note that a major accepted therapy for SLE includes anti-malarial medications, specifically chloroquine and hydroxychloroquine [38-42]. Thus, there are several lines of evidence supporting the idea that a genetic predisposition for immunohyperactivity in conjunction with molecular mimicry may be associated with the initiation of SLE.

\section{Chronic fatigue syndrome}

Chronic fatigue syndrome is closely related to FM and Gulf War Veterans' Illness by several overlapping clinical features [43]. Several infectious aetiologies have been scrutinised for association with CFS. Acute infections by viral and non-viral pathogens have been associated with the subsequent development of CFS in a subset of 
patients [44]. Persistent enteroviruses have been reported in patients with CFS, and there is some symptomology overlap with irritable bowel syndrome $[45,46]$. Most recently, 142 patients with CFS and herpesvirus infections were treated with some reported degree of success [47]. A number of studies cite the role of Mycoplasma sp. and Coxiella burnetti in CFS [48-54]. Currently there are few publications regarding a potential role of protozoa in CFS. Infection by intestinal parasite Giardia sp. has also been correlated with CFS $[55,56]$. It has also been considered, based on a case whereby Acanthamoeba sp. was detected in a previously diagnosed CFS patient [57], that features of CFS may be due to an immunocompromised status. It is also of note that CFS patients present with significantly increased antibody titres to various Apicomplexan protozoa, such as Toxoplasma gondii and Sarcocystis sp. [58]. Then, CFS appears to have an infectious component. However, it is unclear if the direct activity of an infection or if an immunological failure is responsible for the disease presentation.

\section{Fibromyalgia}

Bacteria have been studied to some extent, with various Mycoplasma species and viral organisms showing some level of non-trivial prevalence. However, neither significant clinical impact nor adoption of new treatment modalities has resulted from this research [52]. Doxycycline, an adjunctive medication in the treatment of malaria, has been utilised in the treatment of FM patients $[53,59]$, and this drug has been shown to be effective, although the mechanism was proposed to be due to a global anti-inflammatory effect $[60,61]$.

\section{Multiple sclerosis}

A number of studies have been published on the potential protozoal role in MS. Reports dating back to the late 1800s support and suggest that a malaria-like organism might be associated with MS $[62,63]$. It is interesting to note that seasonal tick emergence, and potentially other disease vectors, have geographic and timing associations with the prevalence of MS [64]. Furthermore, many studies have shown efficacy of doxycycline and minocycline therapy in the treatment of MS [65-73]. It has been speculated that the mechanism of these antibiotics in the treatment of MS is related to their anti-inflammatory effects, but such an effect has not been conclusively demonstrated. Of note, doxycycline is used for the prophylaxis and treatment of malaria [74-81].

\section{Amyotrophic lateral sclerosis}

Arguably one of the most studied and most conflicting series of results is that regarding the potential viral aetiology of ALS [82-84]. Suspected culprits include polioviruses [85], enteroviruses [85-90], herpesviruses (HHV-6, HHV-7, HHV-8 [91-93]), echoviruses (ECHO6 and ECHO7 [92, 94]), and even human endogenous retroviruses [95]. This line of inquiry is likely spurred by the continued findings of reverse transcriptase activity in patients with ALS $[96,97]$ and reversible ALS-like symptoms that are sometimes observed in HIV patients [98-101]. However, anti-retroviral therapies have yielded no improvements in patient outcome [102]. Bacteria have also been studied, whereby Borrelia burgdorferi (the causative organisms for Lyme disease) [103, 104], Mycoplasma sp. [105], and cyanobacteria have all been considered as potential associated factors [106]. It has been reported, as with multiple sclerosis, that the seasonal emergence of ticks is connected with ALS risk [64]. It is clear that patients who suffer from ALS have an increased risk of acute sepsis; however, that risk is elevated post-diagnosis [107]. In addition, there continues to be concern about transplanting organs from diseased ALS patients to healthy individuals as the possibility of transmission of the disease has not been ruled out [108].

\section{Atherosclerotic arterial plaque}

Microbial and viral involvement in atherosclerosis has been previously hypothesised and studied [109]. The presence of Cytomegalovirus has been reported in atherosclerotic plaques in 105 patients with acute coronary syndromes [110]. A cell biology potential of macrophages to transition to foam cells has been suggested whereby macrophages have reduced liver X receptor- $\alpha$ in atherosclerotic arteries when infected with Chlamydia pneumoniae [111]. In further support, Chlamydia pneumoniae antigens have been detected in coronary atheroma [112] as well as early atherosclerotic plaques [113]. However, an analysis of arterial plaques failed to detect Chlamydia pnenumoniae, HSV1, or Cytomegalovirus, but EBV was detected [114]. Additionally, a wide range of oral flora has been detected using PCR amplification techniques in vascular disease samples [115]. It is interesting to note that Porphyromonas gingivalis [116], Streptococcus mutans [117], and polymicrobial infections [118] have been shown to accelerate inflammatory atherosclerosis in ApoE mutant mice. To further support the dental flora hypothesis, aortic endothelial cells are invaded by viridans group of Streptococci and have been shown to induce an inflammatory response [119]. Invasion by microbes also appears to favour other host changes that influence arterial plaque formation, as in the case where Porphyromonas gingivalis accelerated atheroma formation by altering the lipid profile in the host [120]. Helicobacter sp. has also been detected in atherosclerotic plaques [121]. Indirectly, bacterial signatures have been found in thrombi derived from patients with myocardial infarction [122]. It has been suggested that statins modify cardiovascular risk via antimicrobial activity rather than through modification 
of lipid profiles [123]. Taken in total, no common thread beyond sporadic and inconsistent microbial involvement has been identified, and currently no studies have specifically assessed protozoal involvement in arterial plaque or in the debris resulting from angioplasty.

\section{DISCUSSION}

Here we have demonstrated the presence of mixed putative biofilm communities in six patients with a range of chronic inflammatory and autoimmune diseases. The identified bacteria include both known and potentially novel organisms. All samples have prominent protozoan components as suggested by microscopy and by clinical metagenomic analysis. The sequences identified in SLE are consistent with a novel organism, candidatus Protomyxzoa rheumatica (GenBank\# KJ914572). In FM, MS, ALS, and angioplasty debris the identified protozoa are potentially of aquatic origin. Generally, the primary identified protozoa are potentially related to known pathogens of animals, thus raising the possibility of zoonotic infection or transmission. It is possible that these organisms may enter a human host via insect vectors, contaminated water, or contaminated food.

It is quite possible that these microorganisms, with additional inquiry, may be eventually considered a benign human flora, in a similar way to how the Human Microbiome Project has expanded the understanding of the diversity of normal intestinal microbiota [124]. Most of the bacteria identified in our samples could be considered incidental, as their opportunistic or non-pathogenic cladistic assignments suggests. However, the potential pathogenic nature of the others, primarily that of detected protozoa, warrants additional inquiry.

The greatest cause of death in the modern world is cardiovascular disease. Various microbes have been demonstrated in atherosclerotic plaques. However, no targeted metagenomic analysis of angioplasty debris has been previously performed. Previous research has linked the dependence of parasitic apicomplexans, such as Babesia sp., Toxoplasma gondii, and Plasmodium sp., to host lipid and cholesterol profiles [125-129]. Additionally, some aspects of host immunological response appear to be-in part-affected by serum lipoproteins and lipid content [130,131]. Taken into consideration with our arterial angioplasty findings, a shared mechanism between host lipid levels, microbial dependence, and immune system modulation suggests that atherosclerosis may be a multifactorial process that includes a previously unrecognised polymicrobial component. To date, no studies have extensively targeted protozoa in atherosclerosis; although previous reports have indicated the presence of aberrant eukaryotic cells [132] in addition to well-studied inflammatory processes. These results may be consistent with a complex community of bacteria and protozoa in the developing atherosclerotic plaque.
Detection of potentially pathogenic protozoa may be of great clinical significance. Fungal and archaea contribution were not specifically targeted. However, our primer pairs have been shown to amplify a significant portion of these organisms. In the future we plan to specifically target fungi, archaea, and viral contribution using a similar metagenomic approach.

Intravascular abnormalities, such as webs and septa, as well as other unusual findings observed via ultrasound (so-called chronic cerebrospinal venous insufficiency CCSVI) have been reported in MS patients [133-137]. It may be that similar structures to those observed in the FM case (large thrombotic-like strands) may also be present in MS patients. However, endovascular attempts to remove these blockages have had varying degrees of success in reversing symptoms of MS [134, 138-154]. The formation of streamers by bacterial biofilms in a cardiovascular stent model has been shown to produce a dramatic reduction in flow rate similar to that seen in CCSVI [155]. We hypothesise that the haemodynamic flow change observed in CCSVI may be due to such a polymicrobial biofilm phenomenon.

Additional corroborating data that indicates involvement of microbes in these diseases include treatments that have been demonstrated to be efficacious in the absence of a clear mechanism of action. Therapy for SLE includes chloroquine hydrochloride, which is also an anti-malarial drug used worldwide [38-42, 156]. Anti-malarial treatments including quinine derivatives, doxycycline, and minocycline have also been shown to be efficacious in the management of MS [65-67, 69-73, 157]. In CFS, the use of doxycycline has been shown to be efficacious and produce symptom improvement $[59,158]$. There have been anecdotal reports of ALS patients utilising antimicrobials and experiencing extended survival rates; however, no comprehensive study exists to date. It is also important to note that antimicrobial therapies are not curative in these diseases. It is unclear if this is most consistent with these organisms being involved in the disease progression if these organisms are inherently recalcitrant as observed in polymicrobial biofilm communities, or if their presence is a consequence of dysfunction of the immune system in the patient.

In light of the reported results, clinical observations, and current literature we propose the following scenario in these polymicrobial biofilm infections. An initial insult is the protozoan entry into the bloodstream, probably vector mediated (mosquito, tick, or another arthropod), although parenteral routes are also possible. An incubation period of days to weeks ensues, and then there is a time of illness with malaise and flulike symptoms. In the majority of affected individuals there is a remission, and some may experience persistent malaise and progressive clinical symptoms. If such a microorganism persists in a biofilm community, it may become protected from immune and inflammatory responses by polysaccharides, 
nucleic acids, and peptides building the biofilm scaffold. In periods of emotional stress, illness, trauma, or dietary excess these biofilm communities may resurge and spread as immune surveillance is curtailed. In addition, biofilm can be permanently attached to the vascular wall. Due to quorum sensing and other mechanisms, excessive growth of such a microbial community and parasitic burden is diminished. However, possible cracks in the biofilm could expose the underlying organisms to the immune system, initiating response of the human host. Such disruptions in the biofilm matrix and immune system recognition may be intermittent, which may explain the relapsing and remitting nature of MS.

\section{SUMMARY}

Published evidence does not exclude, and in some instances supports, the involvement of protozoa in many of the above-presented diseases. The role of protozoa in human disease is well known. Malaria, for example, infected more than 219 million and killed 660,000 worldwide in 2010 alone. It is well known that biofilm-dwelling bacteria play a significant role in chronic human disease. Here we suggest that chronic, biofilm-based protozoal infections may be at the heart of a variety of chronic human diseases. Interestingly, in all our patients, except for the patient with SLE (where DNA stains and culture studies revealed a novel microorganism: candidatus Protomyxzoa rheumatica), we demonstrated protozoa being close relatives or already known aquatic-based protozoa.

Based on our results, we hypothesise that biofilmforming protozoa may represent a non-trivial component in human disease and that the human vascular system may be a significant site of colonisation. It was through a number of technological innovations: DNA extraction technology, NGS, and clinical metagenomic analysis, that this work and future projects are possible. It is plausible that there may be previously unrecognised vascular polymicrobial biofilm phenomena that could trigger, potentiate, or contribute to vascular and immunological dysfunction.

\section{ACKNOWLEDGEMENTS}

We would like to thank Avory Henningburg for his technical assistance on components of this project. Funding for these studies is from internal operational funds.

\section{References}

1. Hall-Stoodley L., Costerton J.W., Stoodley P. Bacterial biofilms: from the natural environment to infectious diseases. Nat Rev Microbiol 2004; 2: 95-108.

2. Parsek M.R., Singh P.K. Bacterial biofilms: an emerging link to disease pathogenesis. Annu Rev Microbiol 2003; 57: 677-701.

3. Hall-Stoodley L., Stoodley P. Evolving concepts in biofilm infections. Cell Microbiol 2009; 11: 1034-1043.
4. Mahendra J., Mahendra L., Felix J., Romanos G. Prevelance of periodontopathogenic bacteria in subgingival biofilm and atherosclerotic plaques of patients undergoing coronary revascularization surgery. J Indian Soc Periodontol 2013; 17: 719-724.

5. Okuda K., Kato T., Ishihara K. Involvement of periodontopathic biofilm in vascular diseases. Oral Dis 2004; 10: 5-12.

6. Cushion M.T., Collins M.S., Linke M.J. Biofilm formation by Pneumocystis spp. Eukaryot Cell 2009; 8: 197-206.

7. Ellis J.E., Prochazka M., Fry S.E. Evidence for in-vivo hematologic biofilm communities in 3 patients with ALS. 5th American Society for Microbiology Conference on Biofilms, November 15-19, 2009; Cancun, Mexico.

8. Oberholzer M., Lopez M.A., McLelland B.T., Hill K.L. Social motility in African trypanosomes. PLoS Pathog 2010; 6: e1000739.

9. Koch R. Uber bakteriologische Forschung Verhandlung des X Internationalen Medichinischen Congresses, Berlin 1890, 1, 35. In $10^{\text {th }}$ International Congress of Medicine, Berlin, Germany 1891: August Hirschwald, Berlin (in German).

10. Bhattacharya S., Vijayalakshmi N., Parija S.C. Uncultavatable bacteria: Implications and recent trends towards identification. Indian J Med Microbiol 2002; 20: 174-177.

11. Phua J., Ngerng W., See K., Tay C., Kiong T., Lim H., et al. Characteristics and outcomes of culture-negative versus culture-positive severe sepsis. Crit Care 2013; 17: R202.

12. Bone R.C., Fisher C.J. Jr, Clemmer T.P., Slotman G.J., Metz C.A., Balk R.A. Sepsis syndrome: a valid clinical entity. Methylprednisolone Severe Sepsis Study Group. Crit Care Med 1989; 17: 389-393.

13. Fredericks D.N., Relman D.A. Sequence-based identification of microbial pathogens: a reconsideration of Koch's postulates. Clin Microbiol Rev 1996; 9: 18-33.

14. Claesson M.J., Wang Q., O’Sullivan O., Greene-Diniz R., Cole J.R., Ross R.P., et al. Comparison of two next-generation sequencing technologies for resolving highly complex microbiota composition using tandem variable $16 \mathrm{~S}$ rRNA gene regions. Nucleic Acids Res 2012; 38: e200.

15. Jünemann S., Prior K., Szczepanowski R., Harks I., Ehmke B., Goesmann A., Stoye J., Harmsen D. Bacterial community shift in treated periodontitis patients revealed by ion torrent $16 \mathrm{~S}$ rRNA gene amplicon sequencing. PLoS One 2012; 7: e41606.

16. Whiteley A.S., Jenkins S., Waite I., Kresoje N., Payne H., Mullan B., Allcock R., O’Donnell A. Microbial 16S rRNA Ion Tag and community metagenome sequencing using the Ion Torrent (PGM) Platform. J Microbiol Methods 2012; 91: 80-88.

17. Latt S.A., Stetten G. Spectral studies on 33258 Hoechst and related isbenzimidazole dyes useful for fluorescent detection of deoxyribonucleic acid synthesis. J Histochem Cytochem 1976; 24: 24-33.

18. Latt S.A., Stetten G., Juergens L.A., Willard H.F., Scher C.D. Recent developments in the detection of deoxyribonucleic acid synthesis by 33258 Hoechst fluorescence. J Histochem Cytochem 1975; 23: 493-505.

19. Yu C., Gershwin M.E., Chang C. Diagnostic criteria for systemic lupus erythematosus: a critical review. J Autoimmun 2014; 48-49C: 10-13.

20. Fukuda K., Straus S.E., Hickie I., Sharpe M.C., Dobbins J.G., Komaroff A. The chronic fatigue syndrome: a comprehensive approach to its definition and study. International Chronic Fatigue Syndrome Study Group. Ann Intern Med 1994; 121: 953-959. 
21. Brurberg K.G., Fønhus M.S., Larun L., Flottorp S., Malterud K. Case definitions for chronic fatigue syndrome/myalgic encephalomyelitis (CFS/ME): a systematic review. BMJ Open 2014; 4: e003973.

22. Ragone Calvo L.M., Walker J.G., Burreson E.M. Prevalence and distribution of QPX, Quahog Parasite Unknown, in hard clams Mercenaria mercenaria in Virginia, USA. Dis Aquat Organ 1998; 33: 209-219.

23. Smolowitz R., Leavitt D., Perkins F. Observations of a Protistan Disease Similar to QPX in Mercenaria mercenaria (Hard Clams) from the Coast of Massachusetts. J Invertebr Pathol 1998; 71: 9-25.

24. McDonald W.I., Halliday A.M. Diagnosis and classification of multiple sclerosis. Br Med Bull 1977; 33: 4-9.

25. Carvalho M.D., Swash M. Awaji diagnostic algorithm increases sensitivity of El Escorial criteria for ALS diagnosis. Amyotroph Lateral Scler 2009; 10: 53-57.

26. Itoh N., Meyer G.R., Tabata A., Lowe G., Abbott C.L., Johnson S.C. Rediscovery of the Yesso scallop pathogen Perkinsus qugwadi in Canada, and development of PCR tests. Dis Aquat Organ 2013; 104: 83-91.

27. Harley J.B., Harley I.T., Guthridge J.M., James J.A. The curiously suspicious: a role for Epstein-Barr virus in lupus. Lupus 2006; 15: 768-777.

28. Harley J.B., James J.A. Epstein-Barr virus infection induces lupus autoimmunity. Bull NYU Hosp Jt Dis 2006; 64: 45-50.

29. Poole B.D., Scofield R.H., Harley J.B., James J.A. Epstein-Barr virus and molecular mimicry in systemic lupus erythematosus. Autoimmunity 2006; 39: 63-70.

30. Zhang W., Reichlin M. A possible link between infection with burkholderia bacteria and systemic lupus erythematosus based on epitope mimicry. Clin Dev Immunol 2008; 2008: 683489.

31. Chen M., Aosai F., Norose K., Mun H.S., Ishikura H., Hirose S., Piao L.X., Fang H., Yano A. Toxoplasma gondii infection inhibits the development of lupus-like syndrome in autoimmune (New Zealand Black x New Zealand White) F1 mice. Int Immunol 2004; 16: 937-946.

32. Harley J.B., Kelly J.A., Kaufman K.M. Unraveling the genetics of systemic lupus erythematosus. Springer Semin Immunopathol 2006; 28: 119-130.

33. Bolland S., Ravetch J.V. Spontaneous autoimmune disease in $\mathrm{Fc}$ (gamma)RIIB-deficient mice results from strain-specific epistasis. Immunity 2000; 13: 277-285.

34. Clatworthy M.R., Smith K.G. FcgammaRIIb balances efficient pathogen clearance and the cytokine-mediated consequences of sepsis. J Exp Med 2004; 199: 717-723.

35. Takai T. Roles of Fc receptors in autoimmunity. Nat Rev Immunol 2002; 2: 580-592.

36. Takai T., Ono M., Hikida M., Ohmori H., Ravetch J.V. Augmented humoral and anaphylactic responses in Fc gamma RII-deficient mice. Nature 1996; 379: 346-349.

37. Clatworthy M.R., Willcocks L., Urban B., Langhorne J., Williams T.N., Peshu N., Watkins N.A., Floto R.A., Smith K.G. Systemic lupus erythematosus-associated defects in the inhibitory receptor FcgammaRIIb reduce susceptibility to malaria. Proc Natl Acad Sci U S A 2007; 104: 7169-7174.

38. Lanham J.G., Hughes G.R. Antimalarial therapy in SLE. Clin Rheum Dis 1982; 8: 279-298.

39. Lee S.J., Silverman E., Bargman J.M. The role of antimalarial agents in the treatment of SLE and lupus nephritis. Nat Rev Nephrol 2011; 7: 718-729.
40. Momose Y., Arai S., Eto H., Kishimoto M., Okada M. Experience with the use of hydroxychloroquine for the treatment of lupus erythematosus. J Dermatol 2013; 40: 94-97.

41. Ruiz-Irastorza G., Ramos-Casals M., Brito-Zeron P., Khamashta M.A. Clinical efficacy and side effects of antimalarials in systemic lupus erythematosus: a systematic review. Ann Rheum Dis 2010; 69: 20-28.

42. Wozniacka A., Lesiak A., Narbutt J., Kobos J., Pavel S., SysaJedrzejowska A. Chloroquine treatment reduces the number of cutaneous HLA-DR+ and CD1a+ cells in patients with systemic lupus erythematosus. Lupus 2007; 16: 89-94.

43. Rayhan R.U., Ravindran M.K., Baraniuk J.N. Migraine in Gulf War illness and chronic fatigue syndrome: prevalence, potential mechanisms, and evaluation. Front Physiol 2013; 4: 181.

44. Hickie I., Davenport T., Wakefield D., Vollmer-Conna U., Cameron B., Vernon S.D., Reeves W.C., Lloyd A.; Dubbo Infection Outcomes Study Group. Post-infective and chronic fatigue syndromes precipitated by viral and non-viral pathogens: prospective cohort study. BMJ 2006; 333: 575.

45. Frissora C.L., Koch K.L. Symptom overlap and comorbidity of irritable bowel syndrome with other conditions. Curr Gastroenterol Rep 2005; 7: 264-271.

46. Chia J.K., Chia A.Y. Chronic fatigue syndrome is associated with chronic enterovirus infection of the stomach. J Clin Pathol 2008; 61: 43-48.

47. Lerner M.A., Beqaj S.H., Fitzgerald J.T., Gill K., Gill C., Edington J. Subset-directed antiviral treatment of 142 herpesvirus patients with chronic fatigue syndrome. Virus Adapt Treatment 2010; 2: 47-57.

48. Nijs J., Nicolson G.L., De Becker P., Coomans D., De Meirleir K. High prevalence of Mycoplasma infections among European chronic fatigue syndrome patients. Examination of four Mycoplasma species in blood of chronic fatigue syndrome patients. FEMS Immunol Med Microbiol 2002; 34: 209-214.

49. Nicolson G.L., Gan R., Haier J. Multiple co-infections (Mycoplasma, Chlamydia, human herpes virus-6) in blood of chronic fatigue syndrome patients: association with signs and symptoms. APMIS 2003; 111: 557-566.

50. Nasralla M., Haier J., Nicolson G.L. Multiple mycoplasmal infections detected in blood of patients with chronic fatigue syndrome and/or fibromyalgia syndrome. Eur J Clin Microbiol Infect Dis 1999; 18: 859-865.

51. Marmion B.P., Sukocheva O., Storm P.A., Lockhart M., Turra M., Kok T. Q fever: persistence of antigenic non-viable cell residues of Coxiella burnetii in the host - implications for post $\mathrm{Q}$ fever infection fatigue syndrome and other chronic sequelae. QJM 2009; 102: 673-684.

52. Ledina D., Bradarić N., Milas I., Ivić I., Brncić N., Kuzmicić N. Chronic fatigue syndrome after Q fever. Med Sci Monit 2007; 13: CS88-92.

53. Endresen G.K. Systemic Mycoplasma blood infection in fibromyalgia and chronic fatigue syndrome. Tidsskr Nor Laegeforen 2004; 124: 203-205.

54. Choppa P.C., Vojdani A., Tagle C., Andrin R., Magtoto L. Multiplex PCR for the detection of Mycoplasma fermentans, M. hominis and M. penetrans in cell cultures and blood samples of patients with chronic fatigue syndrome. Mol Cell Probes 1998; 12: 301-308.

55. Naess H., Nyland M., Hausken T., Follestad I., Nyland H.I. Chronic fatigue syndrome after Giardia enteritis: clinical characteristics, disability and long-term sickness absence. BMC Gastroenterol 2012; 12: 13. 
56. Mørch K., Hanevik K., Rivenes A.C., Bødtker J.E., Næss H., Stubhaug B., Wensaas K.A., Rortveit G., Eide G.E., Hausken T., Langeland N. Chronic fatigue syndrome 5 years after giardiasis: differential diagnoses, characteristics and natural course. BMC Gastroenterol 2013; 13: 28.

57. Jhanji V., Beltz J., Vajpayee R.B. Contact lens-related acanthamoeba keratitis in a patient with chronic fatigue syndrome. Eye Contact Lens 2008; 34: 335-336.

58. Pamphlett R., O’Donoghue P. Antibodies against Sarcocystis and Toxoplasma in humans with the chronic fatigue syndrome. Aust N Z J Med 1992; 22: 307-308.

59. Endresen G.K. Mycoplasma blood infection in chronic fatigue and fibromyalgia syndromes. Rheumatol Int 2003; 23: 211-215.

60. Zachrisson O., Colque-Navarro P., Gottfries C.G., Regland B., Möllby R. Immune modulation with a staphylococcal preparation in fibromyalgia/chronic fatigue syndrome: relation between antibody levels and clinical improvement. Eur J Clin Microbiol Infect Dis 2004; 23: 98-105.

61. Vermeulen R.C., Scholte H.R. Azithromycin in chronic fatigue syndrome (CFS), an analysis of clinical data. J Transl Med 2006; 4: 34 .

62. Kissler H. Is multiple sclerosis caused by a silent infection with malarial parasites? A historico-epidemiological approach: part II. Med Hypotheses 2001; 57: 292-301.

63. Kissler H. Is multiple sclerosis caused by a silent infection with malarial parasites? A historico-epidemiological approach: part I. Med Hypotheses 2001; 57: 280-291.

64. Fritzsche M. Geographical and seasonal correlation of multiple sclerosis to sporadic schizophrenia. Int J Health Geogr 2002; $1: 5$.

65. Zhang Y., Metz L.M., Yong V.W., Bell R.B., Yeung M., Patry D.G., Mitchell J.R. Pilot study of minocycline in relapsing-remitting multiple sclerosis. Can J Neurol Sci 2008; 35: 185-191.

66. Zabad R.K., Metz L.M., Todoruk T.R., Zhang Y., Mitchell J.R., Yeung M., Patry D.G., Bell R.B., Yong V.W. The clinical response to minocycline in multiple sclerosis is accompanied by beneficial immune changes: a pilot study. Mult Scler 2007; 13: 517-526.

67. Minagar A., Alexander J.S., Schwendimann R.N., Kelley R.E., Gonzalez-Toledo E., Jimenez J.J., Mauro L., Jy W., Smith S.J. Combination therapy with interferon beta-1a and doxycycline in multiple sclerosis: an open-label trial. Arch Neurol 2008; 65: 199-204.

68. Mikhailoff S. Favorable effects of antibiotics therapy in some cases of parkinsonism and multiple sclerosis. J Med Lyon 1953; 34: 899-901.

69. Metz L.M., Zhang Y., Yeung M., Patry D.G., Bell R.B., Stoian C.A., Yong V.W., Patten S.B., Duquette P., Antel J.P., Mitchell J.R. Minocycline reduces gadolinium-enhancing magnetic resonance imaging lesions in multiple sclerosis. Ann Neurol 2004; 55: 756.

70. Mazdeh M., Mobaien A.R. Efficacy of doxycycline as add-on to interferon beta-1a in treatment of multiple sclerosis. Iran J Neurol 2012; 11: 70-73.

71. Gold R. Combination therapies in multiple sclerosis. J Neurol 2008; 255 (Suppl 1): 51-60.

72. Giuliani F., Fu S.A., Metz L.M., Yong V.W. Effective combination of minocycline and interferon-beta in a model of multiple sclerosis. J Neuroimmunol 2005; 165: 83-91.

73. Chen X., Ma X., Jiang Y., Pi R., Liu Y., Ma L. The prospects of minocycline in multiple sclerosis. J Neuroimmunol 2011; 235: 1-8.
74. Colwell E.J., Hickman R.L., Intraprasert R., Tirabutana C. Minocycline and tetracycline treatment of acute falciparum malaria in Thailand. Am J Trop Med Hyg 1972; 21: 144-149.

75. Kast R.E. Minocycline in cerebral malaria. J Neurosci Res 2008; 86: 3257.

76. Pang L. Doxycycline prophylaxis for malaria. Lancet 1987; 2: 970.

77. Ponnampalam J.T. Doxycycline in the treatment of falciparum malaria among aborigine children in West Malaysia. Trans $\mathrm{R}$ Soc Trop Med Hyg 1981; 75: 372-377.

78. Shanks G.D., Barnett A., Edstein M.D., Rieckmann K.H. Effectiveness of doxycycline combined with primaquine for malaria prophylaxis. Med J Aust 1995; 162: 306-307, 309-310.

79. Tan K.R., Magill A.J., Parise M.E., Arguin P.M. Doxycycline for malaria chemoprophylaxis and treatment: report from the CDC expert meeting on malaria chemoprophylaxis. Am J Trop Med Hyg 2011; 84: 517-531.

80. Taylor W.R., Widjaja H., Richie T.L., Basri H., Ohrt C., Tjitra, Tjitra E., Taufik E., Jones T.R., Kain K.C., Hoffman S.L. Chloroquine/doxycycline combination versus chloroquine alone, and doxycycline alone for the treatment of Plasmodium falciparum and Plasmodium vivax malaria in northeastern Irian Jaya, Indonesia. Am J Trop Med Hyg 2001; 64: 223-228.

81. Willerson D. Jr, Rieckmann K.H., Carson P.E., Frischer H. Effects of minocycline against chloroquine-resistant falciparum malaria. Am J Trop Med Hyg 1972; 21: 857-862.

82. Hudson A.J., Rice G.P. Similarities of guamanian ALS/PD to post-encephalitic parkinsonism/ALS: possible viral cause. Can J Neurol Sci 1990; 17: 427-433.

83. Norris F.H. Jr. Current status of the search for virus in amyotrophic lateral sclerosis (ALS). Neurol Neurocir Psiquiatr 1977; 18 (2-3 Suppl): 443-454.

84. Salazar-Grueso E.F., Roos R.P. Amyotrophic lateral sclerosis and viruses. Clin Neurosci 1995; 3: 360-367.

85. Swanson N.R., Fox S.A., Mastaglia F.L. Search for persistent infection with poliovirus or other enteroviruses in amyotrophic lateral sclerosis-motor neuron disease. Neuromuscul Disord 1995; 5: 457-465.

86. Vandenberghe N., Leveque N., Corcia P., Brunaud-Danel V., Salort-Campana E., Besson G., Tranchant C., Clavelou P., Beaulieux F., Ecochard R., Vial C., Broussolle E., Lina B. Cerebrospinal fluid detection of enterovirus genome in ALS: a study of 242 patients and 354 controls. Amyotroph Lateral Scler 2010; 11: $277-282$.

87. Corcia P., Giraud P., Guennoc A.M., de Toffol B., Autret A. Acute motor axonal neuropathy, enterovirus and Amyotrophic lateral sclerosis: can there be a link? Rev Neurol (Paris) 2003; 159: 80-82.

88. Portegies P., Cohen E.S. Possible etiological role retroviruses and enteroviruses in the development of amyotrophic lateral sclerosis. Ned Tijdschr Geneeskd 2002; 146: 1398-1400.

89. Nix W.A., Berger M.M., Oberste M.S., Brooks B.R., McKenna-Yasek D.M., Brown R.H. Jr, Roos R.P., Pallansch M.A. Failure to detect enterovirus in the spinal cord of ALS patients using a sensitive RT-PCR method. Neurology 2004; 62: 1372-1377.

90. Berger M.M., Kopp N., Vital C., Redl B., Aymard M., Lina B. Detection and cellular localization of enterovirus RNA sequences in spinal cord of patients with ALS. Neurology 2000; 54: 20-25.

91. Sola P., Bedin R., Casoni F., Barozzi P., Mandrioli J., Merelli E. New insights into the viral theory of amyotrophic lateral scle- 
rosis: study on the possible role of Kaposi's sarcoma-associated virus/human herpesvirus 8. Eur Neurol 2002; 47: 108-112.

92. Volpi A. Epstein-Barr virus and human herpesvirus type 8 infections of the central nervous system. Herpes 2004; 11 (Suppl 2): 120A-127A.

93. Cermelli C., Vinceti M., Beretti F., Pietrini V., Nacci G., Pietrosemoli P., Bartoletti A., Guidetti D., Sola P., Bergomi M., Vivoli G., Portolani M. Risk of sporadic amyotrophic lateral sclerosis associated with seropositivity for herpesviruses and echovirus-7. Eur J Epidemiol 2003; 18: 123-127.

94. Kawulak M., Lipniacki A. Absence of echoviral RNA sequences in medulla oblongata samples taken from patients who died of ALS. Neurol Neurochir Pol 2006; 40: 28-33.

95. Alfahad T, Nath A. Retroviruses and amyotrophic lateral sclerosis. Antiviral Res 2013; 99: 180-187.

96. Steele A.J., Al-Chalabi A., Ferrante K., Cudkowicz M.E., Brown R.H. Jr, Garson J.A. Detection of serum reverse transcriptase activity in patients with ALS and unaffected blood relatives. Neurology 2005; 64: 454-458.

97. McCormick A.L., Brown R.H. Jr, Cudkowicz M.E., Al-Chalabi A., Garson J.A. Quantification of reverse transcriptase in ALS and elimination of a novel retroviral candidate. Neurology 2008; 70: 278-283.

98. von Giesen H.J., Kaiser R., Köller H., Wetzel K., Arendt G. Reversible ALS-like disorder in HIV infection. An ALS-like syndrome with new HIV infection and complete response to antiretroviral therapy. Neurology 2002; 59: 474.

99. Cone L.A., Nazemi R., Cone M.O. Reversible ALS-like disorder in HIV infection. An ALS-like syndrome with new HIV infection and complete response to antiretroviral therapy. Neurology 2002; 59: 474.

100. Moulignier A., Moulonguet A., Pialoux G., Rozenbaum W. Reversible ALS-like disorder in HIV infection. Neurology 2001; 57: 995-1001.

101. MacGowan D.J., Scelsa S.N., Waldron M. An ALS-like syndrome with new HIV infection and complete response to antiretroviral therapy. Neurology 2001; 57: 1094-1097.

102. Scelsa S.N., MacGowan D.J., Mitsumoto H., Imperato T., LeValley A.J., Liu M.H. A pilot, double-blind, placebo-controlled trial of indinavir in patients with ALS. Neurology 2005; 64: 1298-1300.

103. Halperin J.J., Kaplan G.P., Brazinsky S., Tsai T.F., Cheng T., Ironside A., Wu P., Delfiner J., Golightly M., Brown R.H., Dattwyler R.J., Luft B.J. Immunologic reactivity against Borrelia burgdorferi in patients with motor neuron disease. Arch Neurol 1990; 47: 586-594.

104. Qureshi M., Bedlack R.S., Cudkowicz M.E. Lyme disease serology in amyotrophic lateral sclerosis. Muscle Nerve 2009; 40: 626-628.

105. Nicolson G.L., Nasralla M.Y., Haier J., Pomfret J. High frequency of systemic mycoplasmal infections in Gulf War veterans and civilians with Amyotrophic Lateral Sclerosis (ALS). J Clin Neurosci 2002; 9: 525-529.

106. Stipa G., Taiuti R., de Scisciolo G., Arnetoli G., Tredici M.R., Biondi N., Barsanti L., Lolli F. Sporadic amyotrophic lateral sclerosis as an infectious disease: a possible role of cyanobacteria? Med Hypotheses 2006; 67: 1363-1371.

107. Fang F., Chen H., Wirdefeldt K., Ronnevi L.O., Al-Chalabi A., Peters T.L., Kamel F., Ye W. Infection of the central nervous system, sepsis and amyotrophic lateral sclerosis. PLoS One 2011; 6: e29749.
108. Holmes B.B., Diamond M.I. Amyotrophic lateral sclerosis and organ donation: is there risk of disease transmission? Ann Neurol 2012; 72: 832-836.

109. Ravnskov U., McCully K.S. Infections may be causal in the pathogenesis of atherosclerosis. Am J Med Sci 2012; 344: 391-394.

110. Izadi M., Fazel M., Saadat S.H., Nasseri M.H., Ghasemi M., Dabiri H., Aryan R.S., Esfahani A.A., Ahmadi A., KazemiSaleh D., Kalantar-Motamed M.H., Taheri S. Cytomegalovirus localization in atherosclerotic plaques is associated with acute coronary syndromes: report of 105 patients. Methodist Debakey Cardiovasc J 2012; 8: 42-46.

111. Bobryshev Y.V., Orekhov A.N., Killingsworth M.C., Lu J. Decreased expression of liver $\mathrm{X}$ receptor-alpha in macrophages infected with Chlamydia pneumoniae in human atherosclerotic arteries in situ. J Innate Immun 2011; 3: 483-494.

112. Borel N., Pospischil A., Dowling R.D., Dumrese C., Gaydos C.A., Bunk S., Hermann C., Ramirez J.A., Summersgill J.T. Antigens of persistent Chlamydia pneumoniae within coronary atheroma from patients undergoing heart transplantation. J Clin Pathol 2012; 65: 171-177.

113. Luque A., Turu M.M., Rovira N., Juan-Babot J.O., Slevin M., Krupinski J. Early atherosclerotic plaques show evidence of infection by Chlamydia pneumoniae. Front Biosci (Elite Ed) 2012; 4: 2423-2432.

114. Tremolada S., Delbue S., Ferraresso M., Carloni C., Elia F., Larocca S., Bortolani E., Ferrante P. Search for genomic sequences of microbial agents in atherosclerotic plaques. Int J Immunopathol Pharmacol 2011; 24: 243-246.

115. Zoellner H. Dental infection and vascular disease. Semin Thromb Hemost 2011; 37: 181-192.

116. Hayashi C., Viereck J., Hua N., Phinikaridou A., Madrigal A.G., Gibson F.C. 3rd, Hamilton J.A., Genco C.A. Porphyromonas gingivalis accelerates inflammatory atherosclerosis in the innominate artery of ApoE deficient mice. Atherosclerosis 2011; 215: 52-59.

117. Kesavalu L., Lucas A.R., Verma R.K., Liu L., Dai E., Sampson E., Progulske-Fox A. Increased atherogenesis during Streptococcus mutans infection in ApoE-null mice. J Dent Res 2012; 91: 255-260.

118. Rivera M.F., Lee J.Y., Aneja M., Goswami V., Liu L., Velsko I.M., Chukkapalli S.S., Bhattacharyya I., Chen H., Lucas A.R., Kesavalu L.N. Polymicrobial infection with major periodontal pathogens induced periodontal disease and aortic atherosclerosis in hyperlipidemic ApoE(null) mice. PLoS One 2013; 8: e57178.

119. Nagata E., de Toledo A., Oho T. Invasion of human aortic endothelial cells by oral viridans group streptococci and induction of inflammatory cytokine production. Mol Oral Microbiol 2011; 26: 78-88.

120. Maekawa T., Takahashi N., Tabeta K., Aoki Y., Miyashita H., Miyauchi S., Miyazawa H., Nakajima T., Yamazaki K. Chronic oral infection with Porphyromonas gingivalis accelerates atheroma formation by shifting the lipid profile. PLoS One 2011; 6: e20240.

121. Izadi M., Fazel M., Sharubandi S.H., Saadat S.H., Farahani M.M., Nasseri M.H., Dabiri H., SafiAryan R., Esfahani A.A., Ahmadi A., Jonaidi Jafari N., Ranjbar R., Jamali-Moghaddam S.R., Kazemi-Saleh D., Kalantar-Motamed M.H., Taheri S. Helicobacter species in the atherosclerotic plaques of patients with coronary artery disease. Cardiovasc Pathol 2012; 21: 307-311. 
122. Pessi T., Karhunen V., Karjalainen P.P., Ylitalo A., Airaksinen J.K., Niemi M., Pietila M., Lounatmaa K., Haapaniemi T., Lehtimäki T., Laaksonen R., Karhunen P.J., Mikkelsson J. Bacterial signatures in thrombus aspirates of patients with myocardial infarction. Circulation 2013; 127: 1219-1228, e1-6.

123. Kozarov E., Padro T., Badimon L. View of statins as antimicrobials in cardiovascular risk modification. Cardiovasc Res 2014; 102: 362-374.

124. Turnbaugh P.J., Ley R.E., Hamady M., Fraser-Liggett C.M., Knight R., Gordon J.I. The human microbiome project. Nature 2007; 449: 804-810.

125. Ginsburg H., Landau I., Baccam D. Effect of cholesterol-rich diet on the susceptibility of rodent malarial parasites to chloroquine chemotherapy. Life Sci 1988; 42: 7-10.

126. Holz G.G. Jr. Lipids and the malarial parasite. Bull World Health Organ 1977; 55: 237-248.

127. Mazumdar J., Wilson E.H., Masek K., Hunter C.A., Striepen B. Apicoplast fatty acid synthesis is essential for organelle biogenesis and parasite survival in Toxoplasma gondii. Proc Natl Acad Sci U S A 2006; 103: 13192-13197.

128. Okubo K., Yokoyama N., Takabatake N., Okamura M., Igarashi I. Amount of cholesterol in host membrane affects erythrocyte invasion and replication by Babesia bovis. Parasitology 2007; 134 (Pt 5): 625-630

129. Waller R.F., Ralph S.A., Reed M.B., Su V., Douglas J.D., Minnikin D.E., Cowman A.F., Besra G.S., McFadden G.I. A type II pathway for fatty acid biosynthesis presents drug targets in Plasmodium falciparum. Antimicrob Agents Chemother 2003; 47: 297-301.

130. Bas S., James R.W., Gabay C. Serum lipoproteins attenuate macrophage activation and Toll-Like Receptor stimulation by bacterial lipoproteins. BMC Immunol 2010; 11: 46.

131. Lee J.Y., Plakidas A., Lee W.H., Heikkinen A., Chanmugam P., Bray G., Hwang D.H. Differential modulation of Toll-like receptors by fatty acids: preferential inhibition by $n-3$ polyunsaturated fatty acids. J Lipid Res 2003; 44: 479-486.

132. Damani S., Bacconi A., Libiger O., Chourasia A.H., Serry R., Gollapudi R., Goldberg R., Rapeport K., Haaser S., Topol S., Knowlton S., Bethel K., Kuhn P., Wood M., Carragher B., Schork N.J., Jiang J., Rao C., Connelly M., Fowler V.M., Topol E.J. Characterization of circulating endothelial cells in acute myocardial infarction. Sci Transl Med 2012; 4: 126ra33.

133. Diaconu C.I., Staugaitis S.M., Fox R.J., Rae-Grant A., Schwanger C., McBride J.M. A technical approach to dissecting and assessing cadaveric veins pertinent to chronic cerebrospinal venous insufficiency in multiple sclerosis. Neurol Res 2012; 34: 810-818.

134. Zamboni P., Galeotti R., Menegatti E., Malagoni A.M., Gianesini S., Bartolomei I., Mascoli F., Salvi F. A prospective open-label study of endovascular treatment of chronic cerebrospinal venous insufficiency. J Vasc Surg 2009; 50: 1348-1358.e1-3.

135. ZamboniP.,GaleottiR.,MenegattiE.,MalagoniA.M.,TacconiG., Dall'Ara S., Bartolomei I., Salvi F. Chronic cerebrospinal venous insufficiency in patients with multiple sclerosis. J Neurol Neurosurg Psychiatry 2009; 80: 392-399.

136. Zamboni P., Menegatti E., Weinstock-Guttman B., Schirda C., Cox J.L., Malagoni A.M., Hojanacki D., Kennedy C., Carl E., Dwyer M.G., Bergsland N., Galeotti R., Hussein S., Bartolomei I., Salvi F., Zivadinov R. The severity of chronic cerebrospinal venous insufficiency in patients with multiple sclerosis is related to altered cerebrospinal fluid dynamics. Funct Neurol 2009; 24: 133-138.
137. Al-Omari M.H., Rousan L.A. Internal jugular vein morphology and hemodynamics in patients with multiple sclerosis. Int Angiol 2010; 29: 115-120.

138. Ghezzi A., Annovazzi P., Amato M.P., Capello E., Cavalla P., Cocco E., Falcini M., Gallo A., Patti F., Perini P., Rodegher M.E., Rovaris M., Rottoli M.R., Comi G.; MS Study Group-Italian Society of Neurology. Adverse events after endovascular treatment of chronic cerebro-spinal venous insufficiency (CCSVI) in patients with multiple sclerosis. Mult Scler 2013; 19: 961-963.

139. Zivadinov R., Magnano C., Galeotti R., Schirda C., Menegatti E., Weinstock-Guttman B., et al. Changes of cine cerebrospinal fluid dynamics in patients with multiple sclerosis treated with percutaneous transluminal angioplasty: a case-control study. J Vasc Interv Radiol 2013; 24: 829-838.

140. Hubbard D., Ponec D., Gooding J., Saxon R., Sauder H., Haacke M. Clinical improvement after extracranial venoplasty in multiple sclerosis. J Vasc Interv Radiol 2012; 23: 1302-1308.

141. Zamboni P., Bertolotto A., Boldrini P., Cenni P., D’Alessandro R., D’Amico R., et al. Efficacy and safety of venous angioplasty of the extracranial veins for multiple sclerosis. Brave dreams study (brain venous drainage exploited against multiple sclerosis): study protocol for a randomized controlled trial. Trials 2012; 13: 183.

142. Ghezzi A., Annovazzi P., Cocco E., Coarelli G., Lugaresi A., Rovaris M., Patti F., Capello E., Rodegher M.E., Moiola L., Malucchi S., Salemi G., De Rossi N., Provinciali L., Perini P., Bergamaschi R., Scarpini E., Lus G., Gallo A., Tola M.R., Amato M.P., Rottoli M.R., Bianchi A., Comi G.; MS Study Group-Italian Society of Neurology. Endovascular treatment of CCSVI in patients with multiple sclerosis: clinical outcome of 462 cases. Neurol Sci 2013; 34: 1633-1637.

143. Alroughani R., Lamdhade S., Thussu A. Endovascular treatment of chronic cerebrospinal venous insufficiency in multiple sclerosis: a retrospective study. Int J Neurosci 2013; 123: 324328.

144. Lupattelli T., Bellagamba G., Righi E., Di Donna V., Flaishman I., Fazioli R., Garaci F., Onorati P. Feasibility and safety of endovascular treatment for chronic cerebrospinal venous insufficiency in patients with multiple sclerosis. J Vasc Surg 2013; 58: 1609-1618.

145. Thibault P., Lewis W., Niblett S. Objective duplex ultrasound evaluation of the extracranial circulation in multiple sclerosis patients undergoing venoplasty of internal jugular vein stenoses: A pilot study. Phlebology 2013. doi: 10.1177/0268355513515473.

146. RadakD., Kolar J., Sagic D., IlijevskiN., TanaskovicS., AleksicN., Marinkovic J., Mitrasinovic A., Radak S., Babic S., Matic P., Vlajinac H. Percutaneous angioplasty of internal jugular and azygous veins in patients with chronic cerebrospinal venous insufficiency and multiple sclerosis: early and mid-term results. Phlebology 2013; 29: 367-375.

147. van Zuuren E.J., Fedorowicz Z., Pucci E., Jagannath V.A., Robak E.W. Percutaneous transluminal angioplasty for treatment of chronic cerebrospinal venous insufficiency (CCSVI) in multiple sclerosis patients. Cochrane Database Syst Rev 2012; 12: CD009903.

148. Hampson C.O., Soares G.M., Jaffan A.A. Reported outcomes after the endovascular treatment of chronic cerebrospinal venous insufficiency. Tech Vasc Interv Radiol 2012; 15: 144149. 
149. Mandato K.D., Hegener P.F., Siskin G.P., Haskal Z.J., Englander M.J., Garla S., Mitchell N., Reutzel L., Doti C. Safety of endovascular treatment of chronic cerebrospinal venous insufficiency: a report of 240 patients with multiple sclerosis. J Vasc Interv Radiol 2011; 23: 55-59.

150. Doležal O., Horáková D., Gdovinová Z., Szilasiová J. Serious complication of percutaneous angioplasty with stent implantation in so called "chronic cerebrospinal venous insufficiency" in multiple sclerosis patient. Prague Med Rep 2012; 113: 289-293.

151. Fankhauser G.T., Stone W.M., Fu R., Money S.R. Spiral vein graft for internal jugular bypass in a patient with multiple sclerosis and suspected chronic cerebrospinal venous insufficiency. Ann Vasc Surg 2013; 27: 673.e5-8.

152. Salvi F., Bartolomei I., Buccellato E., Galeotti R., Zamboni P. Venous angioplasty in multiple sclerosis: neurological outcome at two years in a cohort of relapsing-remitting patients. Funct Neurol 2012; 27: 55-59.

153. Zamboni P., Galeotti R., Weinstock-Guttman B., Kennedy C., Salvi F., Zivadinov R. Venous angioplasty in patients with multiple sclerosis: results of a pilot study. Eur J Vasc Endovasc Surg 2011; 43: 116-122.

154. Scalise F., Novelli E., Farina M., Barbato L., Spagnolo S. Venous Hemodynamic Insufficiency Severity Score variation after endovascular treatment of chronic cerebrospinal venous insufficiency. Phlebology 2014. doi: 10.1177/0268355514524193.

155. Drescher K., Shen Y., Bassler B.L., Stone H.A. Biofilm streamers cause catastrophic disruption of flow with consequences for environmental and medical systems. Proc Natl Acad Sci U S A 2013; 110: 4345-4350.

156. Fischer-Betz R., Schneider M. Antimalarials. A treatment option for every lupus patient. Z Rheumatol 2009; 68: 584, 586-590.

157. Metz L.M., Li D., Traboulsee A., Myles M.L., Duquette P., Godin J., Constantin M., Yong V.W.; GA/minocycline study investigators. Glatiramer acetate in combination with minocycline in patients with relapsing-remitting multiple sclerosis: results of a Canadian, multicenter, double-blind, placebo-controlled trial. Mult Scler 2009; 15: 1183-1194.

158. Iwakami E., Arashima Y., Kato K., Komiya T., Matsukawa Y., Ikeda T., Arakawa Y., Oshida S. Treatment of chronic fatigue syndrome with antibiotics: pilot study assessing the involvement of Coxiella burnetii infection. Intern Med 2005; 44: 1258-1263 